Radionuclide Concentrations in Fish

Collected from Jemez, Nambe, and

San Ildefonso Tribal Lakes

P. R. Fresquez

D. R. Armstrong

J. G. Salazar 


\section{DISCLAIMER}

This report was prepared as an account of work sponsored by an agency of the United States Government. Neither the United States Government nor any agency thereof, nor any of their employees, make any warranty, express or implied, or assumes any legal liability or responsibility for the accuracy, completeness, or usefulness of any information, apparatus, product, or process disclosed, or represents that its use would not infringe privately owned rights. Reference herein to any specific commercial product, process, or service by trade name, trademark, manufacturer, or otherwise does not necessarily constitute or imply its endorsement, recommendation, or favoring by the United States Government or any agency thereof. The views and opinions of authors expressed herein do not necessarily state or reflect those of the United States Government or any agency thereof. 


\section{DISCLAIMER}

Portions of this document may be illegible in electronic image products. Images are produced from the best available original document. 


\title{
RADIONUCLIDE CONCENTRATIONS IN FISH COLLECTED FROM JEMEZ, NAMBE, AND SAN ILDEFONSO TRIBAL LAKES
}

\author{
by
}

\author{
P. R. Fresquez, D. R. Armstrong, and J. G. Salazar
}

\begin{abstract}
Radionuclide concentrations $\left({ }^{90} \mathrm{Sr},{ }^{137} \mathrm{Cs}\right.$, ${ }^{238} \mathrm{Pu}$, ${ }^{239} \mathrm{Pu}$, and total uranium) were determined in fish collected from Jemez, Nambe, and San Ildefonso tribal lakes. With the exception of ${ }^{137} \mathrm{Cs}$, all other radionuclides were not significantly different in (stocked) rainbow trout collected from Jemez and Nambe as compared with game fish collected from Abiquiu, Heron, and EI Vado Reservoirs. Although ${ }^{137} \mathrm{Cs}$ levels in trout from Jemez $\left(3.2 \times 10^{-2} \mathrm{pCi}\right.$ per dry gram) and Nambe $\left(7.5 \times 10^{-2} \mathrm{pCi}\right.$ per dry gram) were significantly higher than ${ }^{137}$ Cs concentrations in fish from Abiquiu, Heron, and El Vado, they were still well below the regional statistical (worldwide fallout) reference level (i.e., $<28 \times 10^{-2} \mathrm{pCi}$ per dry gram). Game and nongame fish collected from San Ildefonso contained higher and significantly higher concentrations of uranium, respectively, as compared with fish collected from Abiquiu, Heron, and EI Vado. The higher uranium concentrations in fish from San Ildefonso as compared with fish from Abiquiu, Heron, and EI Vado were attributed to the higher natural soil uranium contents in the area as compared with the geology of the area upstream of San Ildefonso. The effective (radiation) dose equivalent (EDE) from consuming $46 \mathrm{lb}$ of game fish from Jemez, Nambe, and San Ildefonso lakes, after natural background has been subtracted, was $0.013( \pm 0.002), 0.019$ $( \pm 0.012)$, and $0.017( \pm 0.028) \mathrm{mrem} / \mathrm{yr}$, respectively. Similarly, the EDE from consuming nongame fish from San Ildefonso was 0.0092 $( \pm \mathbf{0 . 0 0 8 4}) \mathrm{mrem} / \mathrm{yr}$. The highest calculated dose, based on the mean + 2 standard deviation $(95 \%$ confidence level), was $0.073 \mathrm{mrem} / \mathrm{yr}$; this was $<0.08 \%$ of the International Commission on Radiological Protection permissible dose limit for protecting members of the public.
\end{abstract}

\section{INTRODUCTION}

As part of the Environmental Surveillance Program at Los Alamos National Laboratory (LANL), samples of foodstuffs (produce, game animals, milk, honey, and fish) are routinely collected and analyzed for radiological constituents from surrounding communities to assess the Laboratory's impact on the human food chain. One important component of this program is the assessment of game (surface-feeding) and nongame (bottom-feeding) fish downstream of the Laboratory for radiological contamination-the 
ingestion of fish constitutes one pathway by which radionuclides can be transferred to humans (Nelson and Wicker 1969). Typically, radionuclide concentrations in fish collected from Cochiti Reservoir, a 10,690-acre flood and sediment control impoundment located approximately five miles downstream of the Laboratory, are compared with fish collected from Abiquiu, Heron, and El Vado Reservoirs (Fresquez et al. 1994b). Abiquiu, Heron, and El Vado are located on the Rio Chama River, upstream from the confluence of the Rio Grande and intermittent streams that cross Laboratory lands. These reservoirs are also sufficiently distant from the Laboratory as to be unaffected by airborne emissions.

There are several Native American Pueblo communities located in the general vicinity of LANL, and a request was made by several Pueblo Governors to assess foodstuffs on Pueblo lands for potential radiological contamination. Fruits, vegetables, herbs, pinon nuts, frogs, prairie dogs, birds, fish, deer, and elk have been suggested by the Pueblos for study. Radionuclide contents in produce (Environmental Protection Group 1994), pinon nuts (Salazar 1979), fish (Fresquez et al. 1994b), bees and honey (Fresquez et al. 1994c), and elk (Fresquez et al. 1994a) collected on or around some Pueblo lands have been previously reported. This study reports (1) the concentrations of various radionuclides in fish collected from Jemez, Nambe, and San Ildefonso tribal lakes, and (2) the total effective (radiation) dose equivalent (EDE) to people who may consume fish from these lakes.

\section{METHODS}

Samples of fish were collected using gill nets in the summer of 1993 from Jemez (Holy Ghost Lakes), Nambe, and San Ildefonso Pueblo pond/lakes and from Abiquiu, Heron, and El Vado Reservoirs (Figure 1).

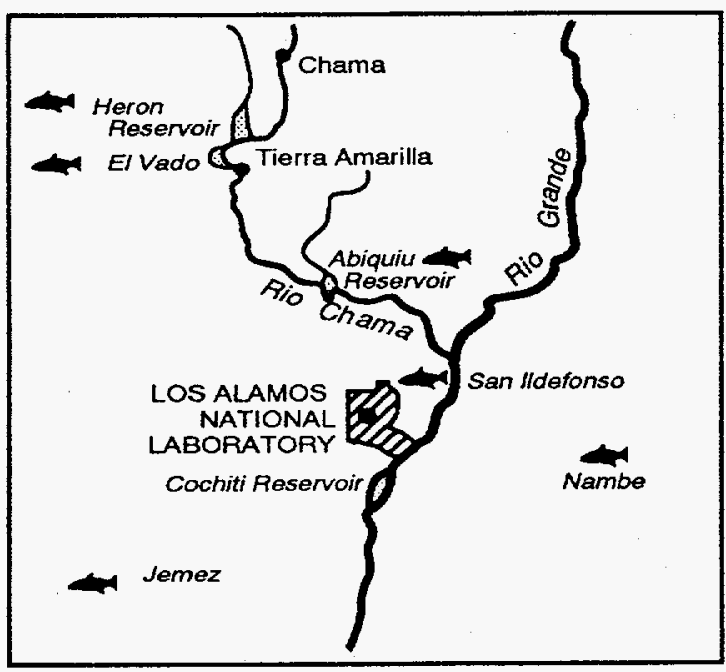

Fig. 1. Fish sampling locations.
Fish collected from Jemez and Nambe Pueblo lakes consisted of (stocked) rainbow trout (Salmo gairdneri), whereas fish collected from San Ildefonso comprised mainly fish indigenous to the (Rio Grande) river. Bass (Micropterus spp.), trout (Salmo spp.), catfish (Ictalurus spp.), suckers (Catostomus spp.), carp (Cprinus spp.), and carp suckers (Carpiodes spp.) were collected at San Ildefonso Pueblo. The 
pond/lake at San Ildefonso was located near the western edge of the Rio Grande, approximately 0.8 miles upstream of the Otowi bridge.

All fish samples were gutted, had their head and tail removed, and were rinsed with distilled water. Approximately $1000 \mathrm{~g}$ of wet fish muscle (and associated skeleton) were placed into tared 1-L beakers and weighed. The beaker contents were oven-dried at $80^{\circ} \mathrm{C}$ for $120 \mathrm{~h}$, weighed, and ashed at $500^{\circ} \mathrm{C}$ for $120 \mathrm{~h}$. The sample ash was weighed, pulverized, and homogenized before it was submitted to the Laboratory for the analysis of ${ }^{90} \mathrm{Sr},{ }^{137} \mathrm{Cs},{ }^{238} \mathrm{Pu},{ }^{239} \mathrm{Pu}$, and total uranium. All methods of radiochemical analysis have been described previously (Salazar 1984). Results are reported on an oven-dry weight basis (dry gram).

The mean radionuclide content in fish collected from each Pueblo pond/lake was compared with fish collected from Abiquiu, Heron, and El Vado Reservoirs at the 0.05 probability level using a Student's t-test (Gilbert 1987). The EDE was calculated using the methodology outlined in the International Commission on Radiological Protection (ICRP) Publication 26 (ICRP 1977) and 30 (ICRP 1978), and the public dose conversion factors in Department of Energy report DOE/EH-0071 (DOE 1984). A dry/wet ratio of 0.25 and an annual consumption rate of $21 \mathrm{~kg}(46 \mathrm{lb})$ were used in the calculation.

\section{RESULTS AND DISCUSSION}

The mean radionuclide data collected for game and nongame fish from three Pueblo pond/lakes and from Abiquiu, Heron, and El Vado Reservoirs located in northern New Mexico can be found in Table 1.

Most radionuclides ${ }^{90} \mathrm{Sr},{ }^{238} \mathrm{Pu},{ }^{239} \mathrm{Pu}$, and total uranium) in (stocked) trout collected from Jemez and Nambe were not significantly different from game fish collected from Abiquiu, Heron, and El Vado Reservoirs. These data, particularly ${ }^{90} \mathrm{Sr}$, compare well with crappie, trout, and salmon data collected from comparable (background) reservoirs and lakes in Colorado (Whicker et al. 1972; Nelson and Wicker 1969). Although ${ }^{137} \mathrm{Cs}$ levels in trout from Jemez and Nambe were significantly higher than fish collected from Abiquiu, Heron, and El Vado, both values were below the regional statistical (worldwide fallout) reference level (i.e., $<28 \times 10^{-2} \mathrm{pCi}$ per dry gram) (Fresquez et al. 1994b). Results of analyses of radionuclides in game and nongame fish samples from Abiquiu, Heron, and El Vado Reservoirs collected from 1981 through 1993 were used to establish statistical limits attributable to natural and/or worldwide fallout of ${ }^{90} \mathrm{Sr},{ }^{137} \mathrm{Cs},{ }^{238} \mathrm{Pu},{ }^{239} \mathrm{Pu}$, and total uranium. The average concentration level in these samples plus twice the standard deviation of the mean was adopted as an indicator of an approximate upper limit for natural or worldwide fallout background concentrations. 
Only one game fish composite sample was collected from San Ildefonso; thus, no statistical comparisons can be made between sites. However, with the exception of total uranium, there were no detectable radiological values (i.e., where the concentration is higher than two times the standard deviation) in the game fish sample collected from San Ildefonso. Total uranium in the game fish sample collected from San Ildefonso was higher than the regional statistical (upper-limit background) reference concentration (i.e., $>6.5$ ng per dry gram).

Table 1. Radionuclide contents in game (surface-feeding) and nongame (bottom-feeding) fish collected from Jemez, Nambe, and San Ildefonso Pueblo pond/lakes as compared with contents in Abiquiu, Heron, El Vado Reservoir fish.

\begin{tabular}{|c|c|c|c|c|c|c|c|c|c|c|}
\hline \multirow{2}{*}{\multicolumn{3}{|c|}{$\begin{array}{r}{ }^{90} \mathrm{Sr} \\
10^{-2} \mathrm{pCi} / \mathrm{dry} \mathrm{g}\end{array}$}} & \multicolumn{2}{|c|}{$\begin{array}{l}{ }^{137} \mathrm{Cs} \\
10^{-2} \mathrm{pCi} / \mathrm{dry} \mathrm{g}\end{array}$} & \multicolumn{2}{|c|}{$\begin{array}{l}\text { Uranium } \\
\text { ng/dry g }\end{array}$} & \multicolumn{2}{|c|}{$\begin{array}{l}{ }^{238} \mathrm{Pu} \\
10^{-5} \mathrm{pCi} / \text { dry } \mathrm{g}\end{array}$} & \multicolumn{2}{|c|}{$\begin{array}{l}{ }^{239} \mathrm{Pu} \\
10^{-5} \mathrm{pCi} / \text { dry g }\end{array}$} \\
\hline & & & & & & & & & & \\
\hline \multicolumn{11}{|c|}{ Jemez (trout) } \\
\hline $\mathrm{N}^{1}$ & 4 & & 4 & & 3 & & 4 & & 4 & \\
\hline Min & 0.6 & $(1.2)^{2}$ & 2.4 & (2.3) & 3.1 & $(6.4)$ & 0.0 & $(36.0)$ & 0.0 & $(24.0)$ \\
\hline $\operatorname{Max}$ & 1.5 & $(3.0)^{2}$ & 4.7 & (3.6) & 8.4 & $(9.2)$ & 16.0 & $(90.0)$ & 30.0 & $(60.0)$ \\
\hline Mean & 1.0 & $(0.8)^{3}$ & $3.2 \mathrm{a}^{4}$ & $(2.2)$ & 5.7 & $(5.2)$ & 6.5 & (15.8) & 14.0 & (25.0) \\
\hline \multicolumn{11}{|c|}{ Nambe (trout) } \\
\hline $\mathrm{N}$ & 4 & & 4 & & 4 & & 4 & & 4 & \\
\hline Min & 0.4 & $(0.8)$ & 2.4 & (1.4) & 1.3 & $(0.2)$ & 0.0 & $(24.0)$ & 0.0 & $(16.0)$ \\
\hline $\operatorname{Max}$ & 1.6 & (1.6) & 14.3 & $(9.8)$ & 4.5 & (1.6) & 8.0 & $(48.0)$ & 8.0 & $(32.0)$ \\
\hline Mean & 0.9 & $(1.0)$ & $7.5 \mathrm{a}$ & $(11.0)$ & 2.9 & $(2.4)$ & 2.0 & $(8.0)$ & 4.7 & $(7.2)$ \\
\hline \multicolumn{11}{|c|}{ San Ildefonso (bass, trout) } \\
\hline $\mathrm{N}$ & 1 & & 1 & & 1 & & 1 & & 1 & \\
\hline Min & 3.6 & (2.4) & 1.5 & (2.6) & 11.8 & (5.2) & 12.0 & $(72.0)$ & 12.0 & $(48.0)$ \\
\hline $\operatorname{Max}$ & 3.6 & $(2.4)$ & 1.5 & (2.6) & 11.8 & (5.2) & 12.0 & $(72.0)$ & 12.0 & $(48.0)$ \\
\hline Mean & 3.6 & $(0.0)$ & 1.5 & $(0.0)$ & 11.8 & $(0.0)$ & 12.0 & $(0.0)$ & 12.0 & $(0.0)$ \\
\hline \multicolumn{11}{|c|}{ Abiquiu, Heron, and EI Vado (trout, salmon, bass, crappie, walleye) } \\
\hline $\mathrm{N}$ & 9 & & 8 & & 9 & & 9 & & 9 & \\
\hline Min & 0.7 & $(1.4)$ & -1.8 & $(2.1)$ & 0.3 & $(0.2)$ & 0.0 & $(42.0)$ & 0.0 & $(40.0)$ \\
\hline $\operatorname{Max}$ & 9.1 & $(2.6)$ & 2.0 & (2.8) & 9.8 & $(2.8)$ & 0.0 & $(90.0)$ & 22.0 & $(44.0)$ \\
\hline Mean & 3.2 & $(5.5)$ & $0.4 b$ & $(2.4)$ & 3.3 & $(5.8)$ & 0.0 & $(0.0)$ & 5.1 & (16.6) \\
\hline \multicolumn{11}{|c|}{ NONGAME FISH (Bottom-feeders) } \\
\hline \multicolumn{11}{|c|}{ San Ildefonso (catfish, sucker, carp, carp sucker) } \\
\hline $\mathrm{N}$ & 3 & & 3 & & 3 & & 3 & & 3 & \\
\hline Min & 1.2 & (1.2) & 0.5 & $(2.3)$ & 10.0 & $(0.2)$ & 0.0 & $(36.0)$ & 0.0 & $(24.0)$ \\
\hline $\operatorname{Max}$ & 8.4 & $(2.8)$ & 0.8 & (2.3) & 16.5 & $(5.0)$ & 6.0 & $(84.0)$ & 14.0 & $(56.0)$ \\
\hline Mean & 4.7 & $(7.2)$ & 0.6 & $(0.3)$ & $14.0 \mathrm{a}$ & $(6.8)$ & 2.0 & $(7.0)$ & 4.7 & $(16.2)$ \\
\hline \multicolumn{11}{|c|}{ Abiquiu, Heron, and EI Vado (catfish, sucker, carp) } \\
\hline $\mathrm{N}$ & 12 & & 11 & & 12 & & 12 & & 12 & \\
\hline Min & 2.1 & (1.4) & -0.2 & $(2.0)$ & 1.6 & $(0.3)$ & 0.0 & $(42.0)$ & 0.0 & $(28.0)$ \\
\hline $\operatorname{Max}$ & 9.8 & (2.8) & 1.8 & $(2.5)$ & 9.5 & $(2.4)$ & 27.0 & $(54.0)$ & 9.0 & $(36.0)$ \\
\hline Mean & 4.7 & (5.3) & 0.8 & (1.3) & $4.3 b$ & $(4.4)$ & 7.6 & $(18.2)$ & 2.9 & $(8.6)$ \\
\hline
\end{tabular}

${ }_{1} \mathrm{~N}=$ number of composite samples.

2 ( \pm counting uncertainty).

3 ( \pm standard deviation).

${ }^{4}$ Means within the same column followed by the same letter are not significantly different at the 0.05 level using a Student's $t$-test. 
No significant differences in ${ }^{90} \mathrm{Sr},{ }^{137} \mathrm{Cs}$, ${ }^{238} \mathrm{Pu}$, and ${ }^{239} \mathrm{Pu}$ levels in nongame fish collected from San Ildefonso as compared with background were detected. Again, total uranium was higher (significant at the 0.05 probability level) in these fish than in comparable fish collected from Abiquiu, Heron, or El Vado; values were slightly lower, however, than the regional statistical (background) reference level, i.e., $<16.2 \mathrm{ng}$ per dry gram. Fish (nongame) collected approximately six miles downstream of San Ildefonso in 1993 showed no evidence of depleted uranium (Fresquez et al, 1994b). Depleted uranium, a by-product of uranium enrichment processes, has been used in dynamic weapons testing at Laboratory firing sites since the mid-1940s (Becker 1992). Instead, the higher uranium concentrations detected in game and nongame fish samples from San Ildefonso were probably a result of the higher natural soil uranium contents in the area as compared with the geology of the area upstream of San Ildefonso. Natural uranium in soils from northern New Mexico and in Bandelier tuff around the Los Alamos area, for example, ranges in concentration from 1.3 to $3.9 \mathrm{ppm}$ (Purtymun et al. 1987) and from 4.0 to $11.4 \mathrm{ppm}$ (Crowe et al. 1978) respectively.

The EDE from consuming $21 \mathrm{~kg}$ (46 lb) of game fish from Jemez, Nambe, and San Ildefonso Pueblo pond/lakes, after subtracting natural background, was 0.013 $( \pm 0.0020), 0.019( \pm 0.012)$, and $0.017( \pm 0.028) \mathrm{mrem} / \mathrm{yr}$ respectively. Similarly, the EDE from consuming nongame fish from San Ildefonso was $0.0092( \pm 0.0084)$. The highest calculated dose, based on the mean +2 standard deviation (95\% confidence level), was $0.0729 \mathrm{mrem} / \mathrm{yr}$; this was $<0.08 \%$ of the ICRP permissible dose limit of $100 \mathrm{mrem} / \mathrm{yr}$ from all pathways. Laboratory operations, therefore, do not result in significant doses, if any, to the general public from consuming fish from either Jemez, Nambe, or San Ildefonso Pueblo pond/lakes.

\section{ACKNOWLEDGMENT}

Special thanks to Belinda Harrigan for constructing Fig. 1 and to Dale Lyons for compiling and tabulating the data. Also, we would like to thank Doug Tederick, biologist, Bureau of Indian Affairs, for the collection of the fish at San Ildefonso.

\section{REFERENCES}

Becker, N. M., "Quantification of Uranium Transport Away From Firing Sites at Los Alamos National Laboratory-A Mass Balance Approach," in Proceedings of the Symposium on Waste Management: Technology and Programs for Radioactive Waste Management and Environmental Restoration, R.G. Post, Ed. (Tucson, Ariz March 1-5, 1992), Vol. 1, pp. 657-659. 
Crowe, B. M., G. W. Linn, G. Heiken, and M. L. Bevier, "Stratigraphy of the Bandelier Tuff in the Pajarito Plateau," Los Alamos National Laboratory report LA-7225MS (April 1978).

Environmental Protection Group, "Environmental Surveillance at Los Alamos During 1992," Los Alamos National Laboratory report LA-12764-ENV (July 1994).

Fresquez, P. R., D. R. Armstrong, and J. G. Salazar, "Radionuclide Concentrations in Elk That Winter on Los Alamos National Laboratory Lands," Los Alamos National Laboratory report LA-12795-MS (July 1994a).

Fresquez, P. R., D. R. Armstrong, and J. G. Salazar, "Radionuclide Concentrations in Game and Nongame Fish Upstream and Downstream of Los Alamos National Laboratory: 1981 to 1993," Los Alamos National Laboratory report LA-12818MS (August 1994b).

Fresquez, P. R., D. R. Armstrong, and J. G. Salazar, "Tritium Concentrations in Bees and Honey at Los Alamos National Laboratory," Los Alamos National Laboratory report LA-12872-MS (November 1994c).

Gilbert, R. O., Statistical Methods for Environmental Pollution Monitoring, Van Nostrand Reinhold, New York, N.Y. (1987).

ICRP, "Recommendations of the International Commission on Radiological Protection," International Commission on Radiological Protection Publication 26, Pergamon Press, New York, N.Y. (1977).

ICRP, "Limits of Intakes of Radionuclides by Workers," International Commission on Radiological Protection Publication 30, Pergamon Press, New York, N.Y. (1978).

Nelson, W.C., and F.W. Wicker, "Cesium-137 in Some Colorado Game Fish, 1965-66," in Symposium on Radioecology, U.S. Atomic Energy Commission report CONF670503, D.J. Nelson and F.C. Evans, Eds., U.S. Atomic Energy Commission, Washington, D.C. (1969). 
Purtymun, W. D., R. J. Peters, T. E. Buhl, M. N. Maes, and F. H. Brown, "Background Concentrations of Radionuclides in Soils and River Sediments in Northern New Mexico, 1974-1986," Los Alamos National Laboratory report LA-11134-MS (November 1987).

Salazar, J. G., "Radionuclide Content of Pinon Nuts in the Vicinity of the Los Alamos Scientific Laboratory," Los Alamos Scientific Laboratory report LA-UR-79-0238 (July 1979).

Salazar, J. G., "Produce and Fish Sampling Program of Los Alamos National Laboratory's Environmental Surveillance Group," Los Alamos National Laboratory report LA-10186-MS (September 1984).

U.S. DOE, "Internal Dose Conversion Factors for Calculation of Dose to the Public," U.S. Department of Energy report DOE/EP-0071 (1984).

Wicker, W. F., W. C. Nelson, and A. F. Gallegos, "Fallout Cs-137 and Sr-90 in Trout from Mountain Lakes in Colorado," Health Physics, 23:519-527 (1992). 